\title{
Symbols of Spite in Hama Tuma's Selected Short Stories
}

\author{
Odhiambo G. Otieno, Doctoral Candidate \\ Edwin Mosoti, PhD \\ Department of Linguistics, Languages, and Literature \\ Jaramogi Oginga Odinga University of Science and Technology \\ Kenya
}

\begin{abstract}
Despotic leadership has been met with a lot of criticism in Africa. Subsequently, the despots have hypocritically reengineered the art of dictatorship by incorporating ornaments of democracy in their leadership so as to project a democratic front purposed to hoodwink the masses. This paper, using the theory of hermeneutics of suspicion, argues that Tuma exposes this hypocrisy of the despots through spiteful symbols that invite the audience to laugh at the despots and their apologists. The paper derives its data from Hama Tuma's five short stories purposively sampled from the thirty four short stories in his anthologies: The case of the socialist witchdoctor and other stories and The case of the criminal walk and other stories. This paper contends that Tuma disapproves of the hypocrisy of the despots and succinctly voices his standpoint by effectively deploying symbols of spite to express his contempt for despotism in Africa and particularly Ethiopia.
\end{abstract}

Keywords: symbols, spite, Hama Tuma, short stories

\subsection{Introduction}

The strand of Africa's failure of leadership has largely been engendered by dictatorship. Due to the wave of democracy, some African despots have whitewashed dictatorial regimes and strategically displayed plastic ornaments of democracy to portray an image of democracy to the cursory onlooker while the reality is otherwise. The tendency of African leaders to exploit existing institutions to their advantage so as to create illusions of democracy is on the rise; for instance, Paul Kagame and Nkurunziza's controversial third term jabs as president, Museveni's age limit debate, Uhuru's 'timely' electoral law reforms after the bungled 2017 general elections, Paul Biya's seventh term victory among others. Such despots employ varied strategies to fasten their grip on power including the dangling of development projects that hoodwink the masses as they remain exploited and oppressed. Today, there is a growing phenomenon of what Matfess (2015) has referred to as "developmental authoritarianism" (p. 3) that is characterized by a State being perceived to be on the path of economic growth though against a backdrop of an oppressed and voiceless citizenry. In such cases, the government of the day ably provides a façade of democratic competition while staving off any serious challenge to power. Ayittey (2012) says that dictatorships owe their success to their manipulation of the main branches of government like the judiciary, electoral commissions, security forces, the media and the central bank. Authoritarian leadership is therefore still prevalent in Africa and among the forces that have countered this vice are the literary artists like Tuma who not only reconstruct but also scornfully magnify the machinations of the despots and the attendant responses of the ruled in the society. This paper relies on the theory of hermeneutics of suspicion to critically examine how the author deploys symbolism to express his disdain for the hypocrisy that engulfs authoritarian setups where the despots project a false image of democracy yet they remain oppressive. Hermeneutics of suspicion which is an amalgamation of Marxist, Freudian, and Nietszche's principles about economics, psychoanalysis, and culture respectively is characterized by a distrust of the symbol as a dissimulation of the real (Ricoeur, 1998, p. 6) hence symbols point to other meanings which though contextually suggested, may not be overtly given.

\subsection{Of Tuma's Symbols of Spite and Despotism}

Tuma uses various symbols to deride the despotic leadership's hypocritical attempt to project a false image of democracy while in reality they remain oppressive. 
This paper begins with an analysis of how the institutional structures of the Kilil and the Queue for Bread have been used by the authorities to stifle the freedoms of the citizenry in Tuma's short stories. It then examines the symbolism of the Alkash and how it typifies the despots. Then follows the symbolism behind the Blue Room, the Pick pocket, and how these symbols cast the character of the despots in Tuma's short stories. This paper holds that these symbols have been deployed by the author to project a leadership that struggles to be perceived as democratic while its actions suggest authoritarianism thereby bringing out the dissident mettle of the author.

\subsection{The Kilil Tether and the Queue for Bread as Administrative Structures}

Tuma's short stories generally interrogate the justice system in Ethiopia. It has been opined that although the Ethiopian government has superficially committed to the ideals of democracy, it has largely disrespected the citizens' freedoms of association, expression, and assembly (HRW, 1997; HRW, 2014; Matfess, 2015). Similarly, Tuma's fictitious society reels in oppression and suppression of the masses by a callous authoritarian regime. The despotic leadership however has beacons of democracy in various fronts meant to hoodwink both the citizenry and any casual observer into thinking that the society is democratically run yet its administrative structures are intended to keep the masses under close check.

\subsubsection{The Kilil Tether}

The repressive government tethers its citizens within paddock like enclosures referred to as kilils - designated regions for particular ethnic groups. Kilils are used to symbolize certain infringements occasioned on the citizens by the authorities ranging from the freedom of movement, speech to association. The accused in 'Criminal Walk' is guilty of walking outside of his kilil without official permission hence the kilils are some loose forms of concentration camps designed by the despotic government to curtail the citizens' freedom of movement. According to the prosecutor, the accused 'Opposed the rules and regulations that have set up the ethnic kilils all over Ethiopia and liberated the people to freely move inside and only inside their own region' (Tuma, 2006, p.58). It is satirical that the government celebrates the kilils for having 'liberated the people to freely move inside and only inside their own region.' This is a façade of freedom of movement. It projects a level of freedom laced with oppressive elements since the citizens' freedom is limited to the whims of the leadership which directly determines the radius of the kilil tether. This government only provides basic freedoms but the fundamental and real freedoms which can be equated to moving beyond the boundaries of one's kilil are limited. A kilil typifies a cage hence the citizens are treated like animals and Tumbo, in Betrayal in the city captures the predicament of such citizens in his statement 'like caged animals, we move, but only inside the cage' (Imbuga, 1987, p.62). In essence, it is a static movement where the kilil connotes the restrictions thrust on the people by the government to keep them under check.

Through the symbol of the kilils, the author crafts a leadership that consciously thrives on fracturing the nation along ethnic lines to bolster its stranglehold on the populace. Each kilil is composed of the same ethnic block and the establishment has 'rules and regulations that have set up the ethnic kilils' (Tuma, 2006, p.58). The agents of the State shamelessly affirm that the general architecture of this government rests on a foundation of ethnicity. The prosecutor says that one of the accusations leveled against the accused is that he has gone 'against the revolutionary ethnic politics of our government' (p.58). The prosecutor's sentiments mask the reality which is that the kilil is a tool for disintegrating the masses and that there is nothing revolutionary in a government squeezing its citizens into ethnic quotas meant to keep them isolated from the rest of the populace. The author laughingly exposes the leadership as sly since they consciously use the kilil to oppress the citizens meanwhile the same public is told of how revolutionary the kilil limitations are to the politics of the nation.

The author is spiteful of the officers who execute the orders of herding the citizens within their kilils and portrays them as both agents and victims of oppression. They execute orders that they hardly understand but the authoritarian system has dehumanized them to an extent that they hardly bother to reflect on their actions. Judge Hagos tells a witness, the police officer who actually arrested the accused, 'I know you are a policeman but sometimes even you must make an effort to think' (Tuma, 2006, p.61). This statement implies that it is normal for the security agents to loyally take orders from their superiors without any due reflection on their actions or the import of such orders. It is not a prerequisite for a police officer to think, at least according to judge Hagos' sentiments, hence they operate like robots. Upon cross examination by the defense attorney, the police officer further reveals the thoughtlessness of security officers' actions in Tuma (2006):

Defense attorney: who decides who gets arrested? 
Policeman (witness): we get orders from our superiors.

Defense attorney: were you ordered to arrest the defendant?

Policeman (witness): yes.

Defense attorney: before you saw him walk or after?

Policeman (witness): he was walking as the security men told us to detain him. (p. 63)

The police officers' actions and speech epitomizes how a dictatorship is run; orders are not interrogated but executed promptly most probably due to the fear and uncertainty within such systems. Tuma further mocks the security agents through the use of hyperbole. The interrogator of twenty five years experience, in self praise and out of encouragement by his superior, accentuates: 'I know a lie before it is uttered ....somewhere in the eyes, the body movement, the curl of the lips' or the prosecutor describing him as a real professional who 'can tell a cross eyed fly from a distance' (Tuma, 2006, p.63) satirizes the hollow but overrated level of professionalism of the security officers who also think of themselves highly yet the government manipulates their actions at will. Their weaknesses notwithstanding, the security officers are very dependable and useful to the despotic authorities.

The regulations that enforce the kilils are unconstitutional. The interrogator is asked whether the accused confessed his guilt and he responds that the accused 'was prattling about his constitutional rights but I told him I never read the said document and he was wasting his time' (p.65). The accused complaining about his 'constitutional rights' implies the existence of a constitutional dispensation that would guarantee one of their democratic spaces. However, this is a document which is basically ornamental and meant to serve as a veneer of democracy for the authoritarian leadership especially given by the contemptuous attitude expressed towards the constitution by the agents of the State. The government interrogator has not read the country's constitution and has no apologies for his ignorance of the contents of the document. It is not surprising therefore that the judge, Hagos, declares that the accused has wasted the time of the court 'through his antics and ridiculous claims of rights and justice' (Tuma, 2006, p.68).

Through the kilil symbol, the author also highlights the lack of freedom of association. The accused is a former teacher and a member of the teachers' association which, though a legal grouping, is detested by the authorities. In an interlocution between the defense attorney and the government witness, the interrogator says that the accused is guilty since he admitted to being a member of the teachers' association and the defense attorney asks: Defense attorney: Isn't the said association legal?

Government witness: Yes, but the government does not like it.

Defense attorney: Is that important so long as it is legal?

Government witness: It is really legal if the government really likes it. (p. 66)

The despotic government therefore relies on the kilil structures to infringe on the citizens' freedom of association since it fears the unity of citizens which would enable the individuals to realize their common status of oppression and possibly unite against the oppressor.

As a chief plank of the kilil structure, the State has undergone great lengths to institute a modern test conducted by a well trained doctor to reveal the ethnic origin of those arrested outside their kilil. It is the leadership's conviction that one's ethnicity speaks to one's character and their socio-political persuasion. The doctor informs the court that the 'Weyin Test' comprises a battery of blood tests and psychological questions including patients being taken through word association to understand their perception of their own life in particular and their country's well being in general. The witness proudly reports, 'We take the patients through word association. When we say Ethiopia most of those who pass the Test mention items or things that do not exist like democracy, dinosaurs, security, enough food' (Tuma, 2006, p.67). The 'Weyin Test' as a component of the kilil hardware is therefore an instrument used to test the citizens' level of loyalty and submission to the despotic leadership. It is ridiculous that those who pass the test are those who, in a bid to please the authorities, affirm the presence of illusive things in the Ethiopian society like democracy. Moreover, those who cross the kilil borders are referred to as 'patients'. The use of the term 'patients' for those who wander outside their kilil implies that those who seek freedom in this society are sick and are subjected to medical treatment in the government 'hospitals' - the torture chambers. Furthermore, though the 'Weyin Test' is praised by the government for its efficiency and scientific backing, the defense lawyer exposes its flaws and even proves before the court that it is not a test recognized by all sectors of the medical profession hence it is just another government friendly tool used to further enhance and give credence to the oppressive system symbolized by the kilil that deprives the citizens of their freedoms. 


\subsubsection{The Queue for Bread}

The daily predicament of the average citizens under a dictatorship is both strained and restrained. The leadership micromanages all their actions as is presented in 'The Case of the Queue Breaker'. The general life of the masses is paralleled to queueing for essential commodities symbolized by 'Bread' at the Central Bakery in the story. While 'Bread' denotes the necessities of life, the Central Bakery stands for the seat of power and its overall monopoly on the provision of essential services to the people. In equating the life of the masses to those on a queue, it is expected of the masses to patiently wait for their turn to be served by the leadership hence conformism. The queue defines interpersonal relations in the society and why such relations have to be adhered to. In Tuma (1993), the narrator muses that the queue offers vital lessons for the citizens on obedience towards the authoritarian leadership and that just as 'everyone has his place in the line, everyone has his place in society. The ones before you or above you have the right to be there.' (p. 65). It is supposedly imperative for the citizens to accept their place in the society without questioning their lot. The leadership is dictatorial since they expect the citizenry not to examine their relations with the leadership but to live in harmony with the despotic structures. There is also lack of accountability on the part of the leadership as they want the masses not to question the circumstances that have occasioned the presence of those who are ahead of them (the leadership) in the queue "they are there because they should be there (p. 65)." Leiter (2004) opines that the rulers clothe their pursuit of self-interest in the garb of morality and justice and in Tuma's story the leadership even invokes the force of their oral tradition to attempt to pacify the people. For example, in defense of their privileged position, they have used the proverb, 'even twins are born one after the other' (Tuma, 1993, p.72) to suggest that it is only fair that everyone accepts their fate. Although the leadership expects citizens to appreciate the fact that there are others in front of them and they have to bide their time, the reality is that it is a long queue and often some people go back home without bread even after queueing for long hours meaning that those in positions of authority often overstay in such posts leading to frustrations among the average citizens.

Those who obey the rules of a queue normally move in a single file implying conformism. Tigist, in 'Queue Breaker', is however accused of willfully violating the institution of the queue. According to the prosecutor, at a time when everybody patiently waited for their turn, she went out of the line disrespecting the order of the queue and demanded immediate service. She defends herself that she saw other people come and do the same leaving her on the line but the prosecutor reiterates that those who broke the queue ahead of her did not break the law since they 'were actually three cadres, two kebele officials, one party member, and one military officer' (Tuma, 1993, p. 69). Insinuated in this context is that the government officers enjoy the privilege of jumping the queue unlike the common citizens who must patiently wait. Essentially, Tuma mocks the selfish and uncaring attitude of the authoritarian leadership that readily access government services without regard for the masses. Having been exposed, their intention to punish Tigist can be explained by Freud's argument that punitive practices and the dominant talk of wrong doing and culpability are only a veneer to desires and drives to life (Harcourt, 2011).

Tuma creates characters that consciously oppose authoritarianism irrespective of the consequences. Tigist maintains that she does not care whether those who jumped the queue ahead of her were State officials or not arguing that the law ought to apply equally to all but she is promptly reminded that the government officials were hurrying to go back to work upon which she sarcastically responds that she was not going back to sleep either. Coated in her disobedience is the notion that the leadership has a duty to set the example of abiding by the law. She actually insists that her action was right since she has no moral obligation obeying laws that are flouted by the leadership itself but the prosecutor swiftly reminds her that State officials 'are the law' (Tuma, 1993, p. 71) intimating that in a dictatorial system the laws are mainly meant to check on the behaviour of the masses. The author deconstructs the myth that the government officials are extra-ordinary people who deserve preferential treatment. In Tigist's estimation these officials are ordinary half literate alcoholics and wife batterers who in all hypocrisy still find their way to church. Through her the masculinity and hypocrisy of the dictatorship is further ridiculed. She scornfully describes one of the officials thus, 'he is ordinary. He gets drunk like all of them, he beats his wife, he goes to church, he learnt to read and write only last year (p. 71). This sentiment provokes the prosecutor into cautioning her against complicating her case further by committing another crime of defamation of a State official. Although Tigist insists that she spoke the truth, the prosecutor holds that even the truth can be illegal meaning that it is the prerogative of the agents of despotism to determine what is legal or illegal hence the indeterminate nature of the truth in a dictatorship. Consequently, and in Nietzsche's understanding, 'punishment serve only to mask the relations of power that have imposed meaning on punishment practices' (Harcourt, 2011, p. 9). 
Moreover, Tigist remains defiant even after being 'treated by the doctors of pain' (p.68) euphemistically suggesting that she stands firm even after being physically tortured by the State operatives hence the author laughs at the futility of the despotic efforts at crushing the opposition.

The Queue symbol portrays the leadership as discriminative, self-centred, and punitive. The masses have the onus of remaining on the queue at whatever cost while those in authority are permitted to jump the same queue at will. The narrator in Tuma (1993) holds that breaking the queue is a serious crime for the citizens though government officials are not expected to queue, 'whenever they come, they are served first' (p. 67). While there are many people queueing for services, the government officials have the luxury of jumping the queue making them callous and indifferent to the plight of the masses. Moreover, any attempt at questioning the actions of the authorities is met with cruel punishment. Tigist is tortured by the State agents and her final sentence ensures that she will be made to 'queue everyday from 2 a $\mathrm{m}$ till noon and to be sent back to the tail-end of the queue every time she reaches the front' (p.72) for a period of three months. The leadership is therefore oppressive and strives to coerce the citizens into submission. In addition, the prosecutor holds that this case is very significant and should be treated as symbolic since 'millions of queuers are awaiting its outcome' (p.68).

\subsection{The Alkash Metaphor}

Nietzsche has argued in Genealogy of Morals that mankind is imbued with emotion which they involuntarily release when faced with suffering and that 'the release of emotion is the greatest attempt at relief, at anaesthetizing on the part of the sufferer' (GM III: 15). Failure to exhibit certain natural emotions therefore signals a misnomer in the society. Tuma's short stories ridicule the hypocrisy of despotic leadership especially during somber moments of loss. The main character in 'Anderibi' was abandoned by the father at two months and the mother died when she was thirteen effectively rendering her an orphan. She was then adopted by an aunt who not only sold Ethiopian indigenous beer tella and tej to men but also supplemented her income by prostitution and the Alkash trade (a professional tear jerker). The narrator describes the brief of an Alkash in Tuma (2006) saying: She was hired to make people cry for the dead at funerals and while she whipped up the funeral crowd, especially women, to a frenzy of chest beating and hair pulling, she hardly ever shed a tear herself. After all, she did not know most of the dead she had to wail for to get paid (p.48).

The Alkash is neither related to the dead nor the relatives of the dead and would have serious challenges responding to Mark Anthony's question to the mourners of Julius Caesar, 'What cause withholds you then to mourn for him? / O judgment, though art fled to brutish beasts/ And men have lost their reason! (Wells, 1989:369) Perhaps the Alkash would respond that there is enough reason in her trade in the name of material gain. She has a duty to remind the dead that one of their own is dead and that they ought to be melancholic about it. She has to solicit, urge or goad the relatives of the dead for tears. The Alkash is betwixt and between the dead and their immediate kin negotiating between the loss occasioned by death and the emotional faculties of the relatives and must pump sense into the living about their attachment to the departed. This portrays a society that is emotionally unavailable. The ordinary members of the society have been oppressed to the extent that they have lost their emotional feelings. In a sense, their suffering has made them immune to basic human feelings such as sorrow since their very life is a tragedy. They are untouched by the death of one of their own and have to be massaged by an outsider to gather their emotional sense. Like Enock's zeal in Chinua Achebe's Things fall apart, the Alkash is the outsider who weeps louder than the bereaved. The Alkash is the leader of the mourning trance, she whips the emotions of the relatives of the dead yet she hardly sheds a tear. She is therefore symbolic of a leadership that is both hypocritical and indifferent to the socio-political conditions of the country - she rallies others to do what she herself has no emotional attachment to. It is a leadership that is also exploitative. The Alkash or 'All cash' has to squeeze out the mourners' tears to get paid the same way the leaders exploit the poor workers to maintain their positions of authority which also guarantee their continued luxury. In addition, the Alkash metaphor projects a society that is gender insensitive. Being a woman and that the Alkash mainly succeeds in working the emotions of fellow women essentially borders on gender stereotypy. At one level, one sees women as people who are easily moved emotionally yet from another angle it projects women as somehow sensible enough to realize, albeit after a reminder, that they ought to mourn their dead /their situation and hence are not as callous and indifferent as the men folk who coincidentally form the bulk of the leadership in this society. 


\subsection{The Blue Room and its Patrons}

In 'Sheratonians' there is a Blue Room inside a Sheraton hotel and all the events in the story are generally anchored on the characters and activities of the patrons of the blue room and how they relate amongst themselves and to the society at large. More specifically, the story revolves around six friends - four gentlemen, Dr. Alex, Tadesse, Abiyou, and Muktar and two ladies namely Roman and Ijigayehu - who believe they are intellectuals of repute in their country and patriots to boot. The blue room itself has been used symbolically to expose the hypocrisy of its patrons. The author further uses these characters to interrogate the siblings rivalry between the diasporic Ethiopian intellectuals and the local/ home based intellectuals with the latter doubting the commitment of the former to the course of their native country or continent. The intellectuals in the diaspora are perceived as traitors and subsequently referred to as hyphenated Ethiopians. Tuma delves on the antagonism between the local and foreign based intellectuals in terms of which group is more committed to the mother country than the other. However, to the authorities these intellectuals are all the same irrespective of their place of residence. In a tone of contempt, the prosecutor in 'Socialist Witchdoctor' tells the judge and indeed all present in court that he hopes the prisoner's case 'will be educational to other demented intellectuals who are sulking inside the country or in comfortable exile in imperialist lands' (Tuma, 1993, p. 51).

The Blue Room is a hall of hypocrisy. Although the patrons of the blue room accuse the exiles of identity crisis, they are equally alienated. Roman is dogged by the problem of identity. She is described as 'short, earth-eyed, slim but bosomy, with a round face covered by excessive make up' (Tuma, 2006, p.149). The use of make up here proffers trying to be what one is not to achieve some end - beauty. Moreover, when 'excessive' then it beats the very purpose for which it is intended. Their sense of beauty is not in consonance with the African ideals. Roman tells Tadesse, 'For men like you, beauty is a straight nose and a slim body well wrapped in a Lacroix smelling of Dior perfumes' (p.151) and Teddy, the narrator says, refrains from telling Romy that her own lampooning statement was almost defining herself. In actual sense, therefore, both the genders have been alienated. The author's argument is that Western modernity holds sway among the local elites too and that ideological positioning transcends one's geographical location. Moreover, though these local based intellectuals question the strength of the commitment of the foreign based intellectuals, their own commitment to the ideals of good governance in their own country is in doubt. Through the Sheraton Six, the author ridicules the commitment and drive of the local Ethiopian intellectuals who have adopted a hollier-than-thou attitude in their vitriolic attack against the diasporic intellectuals. The home based scholars seem to believe that they are unique though they feel that they are surrounded by a citizenry that hardly grasps anything due to their level of illiteracy. Roman compares themselves and the foreign based intellectuals by saying, "they are no more hyphenated than us ... we are intellos in a country of crass illiterates and therefore anomalies quoi' (p.149). These home based scholars know they are living a lie characterized by conformism yet their conscience remains undisturbed. Their main aim is survival despite the many social ills committed by the leadership which to an extent they are part of. Even if they are not part of it, their silence hugely contributes to furthering misrule in the country. Tadesse hints at this when he muses 'we can also be faulted ... we softly criticize the government, we claim to be above it all, don't we? And yet we bow and live this life of ours which the millions cannot imagine let alone have' (Tuma, 2006, p.152)

The Blue Room is largely symbolic. The Oxford Advanced Learner's Dictionary ( $8^{\text {th }}$ ed.) defines 'room' as a part of a building that has its own walls, floor, and ceiling and is usually used for a particular purpose. The term 'room' then connotes some space for a particular activity. It is the activity that takes place in a room that defines the room. For example, there may be a study room, bathroom, waiting room, dining room among others. This space is occupied by some people and its boundaries definitely keep others outside. The Sheraton Six are regular patrons of a bar. They 'were seated at their usual table at the far corner of the Blue Room of the bar in the exclusive Sheraton Hotel. This was their usual haunt be it morning, afternoon or night' (Tuma, 2006, p.149). The color 'blue' heavily resonates with the character and activities of the patrons of the room. Sheraton Hotel's Blue Room, being exclusive, can only be visited by members of a certain class hence discriminative. The group gathered in the Blue Room is microcosmic of the leadership in this society since the 'high class power' congregated in the Blue Room. The patrons of the blue room are therefore representative of the leadership and their hypocrisy tells the story of a government that does not want to mingle with the very people it purports to lead. They have fenced themselves off and away from the reach of the common people. Indeed, not everybody could access the Blue Room due to the fact that: 
Security and class demanded that the ones allowed entry be only those in high positions of power or those associated with or vouched for by them, and high prized whores who are always found where high class power congregates ... entry into the Blue Room and being accepted as a regular was a status symbol (p. 157)

In essence, the intellectuals at home equally own their distinct space which though located within the country, alienates them from the masses. Like the leadership, they are conscious of the fact that there is something that sets them apart from the underprivileged people who can hardly afford to come to this hotel. Tuma laughs at the intellectuals who, like the rulers, would rather barricade themselves in the fantasy of the luxurious hotel than face the harsh reality outside the confines of the hotel and Tadesse says that although they are Ethiopians, they are "not so mundane or pedestrian like the masses in the stinking streets. ... We are aliens in our own City. Why do you think we congregate together here in this luxurious hotel that has little of Ethiopia to it?' (PP. 149 - 150). The answer to this otherwise rhetorical question is that these home based intellectuals are alienated just like their foreign based colleagues. They could be in their home country but they are similarly dislocated from the Ethiopian reality. To begin with, membership to this group implies adhering to already set rules of engagement. At the point when a new member, Gatachew, is to join them, there is general unease among the regulars and as a precautionary measure, Dr. Alex spells a raft of quick lessons for him, 'By God, man, teach him the basics. Dark sunglasses, car with dark shaded windows, no strolling during the day, no eyes for the riffraff millions on the streets. Perfumed handkerchiefs (P.160). All these are conscious attempts by members of the group to alienate themselves from the masses. It is satirical that they live in this country but they detest its sight and smell and have to wear imported sunglasses and perfumes during their interaction with the Ethiopian reality. Besides, they deliberately conceal their identity in their dark shaded windowed cars and they loathe mingling with the commoners. Moreover, the Sheratonians have a keen taste for European products as is attested to by their drinks and food in the bar. They only drink imported brands like Martini Dry, Chivas Regal Whisky among others, they also eat Belugia Caviar and other aperitifs imported from France and Italy. The Blue Room is subsequently symbolic of a class of citizens who are absurdly alienated from the realities of their own country but in their resplendent garb of hypocrisy readily displace this blight on those intellectuals who live away from home.

Many scholars have been tantalized by the colour symbol over time and indeed the colour blue occurs in different tints and has been perceived as having more complex and contradictory meanings than any other colour (Sloane, 1991; Gage, 1993). The colour symbol, argues Haibing (2015), can play an important role in shaping the characters, developing the plot and deepening the theme of a work of art. In 'Sheratonians' the 'blue' in the Blue Room suggests an array of meanings depending on the characters involved and their actions. Since the activities of the patrons of the blue room normally take centre stage at night, the colour dark blue would be associated with them. Although dark blue is often associated with depth, expertise and stability the use of the colour blue in this story is laced with a lot of satire. Gage (1993) observes that many cultures have tended to associate the colour blue with tranquility and calmness and indeed the Sheraton Six superficially project a group of calm and collected intellectuals who seem to understand what is wrong with their colleagues in the diaspora while inwardly the author presents a group of depressed individuals who are hardly at peace with themselves because of a past that they cannot come to terms with. Consequently, the Blue Room portends despondency. Romy had lost a prospective husband to her younger and more beautiful sister who left with a French doctor to Paris, something she is not about to forget. On his part, Tadesse is a chain smoking alcoholic who is only tolerated by most people because he is a good conversationalist and an 'intello' from the great United States of America. Tadesse and Roman are themselves pseudo intellectuals in as much as their group dismisses the exiled intellectuals as lacking in intellectual depth. Both are alienated and have dubious academic backgrounds with equally vague intellectual capacities. The narrator scornfully reveals in Tuma (2006) that: If Roman was a graduate of the City's only Lycee and a fully fledged Francophone who had started and never finished her university studies in Grenoble, France, Tadesse, was a product of a non descript college in South Western USA where all students necessarily graduated with a degree and none failed to make it (p.148)

Another member, Abiyou, is a highly paid lawyer who had studied in Canada and liked to be referred to as Abe just as Abraham Lincoln. Although he is a rich and successful lawyer, he is consumed by hatred and afflicted by his secret burden, he is gay - an alien practice to the African culture - which he has to cover up for by equally immoral but socially accepted slips like 'I must confess that I enjoy a night with young fresh girls' (p.163). Coincidentally, the Russian word for 'light blue' denotes a homosexual. His compatriot, Eskinder, loves to be referred to as Dr. Alex. He is described as a university professor who spotted a Trotsky goatee. 
Though he was once a radical scholar and an intellectual of repute in the California university campuses, he plunged himself into drugs, alcohol, and women. With his health on the red, he returned home and became the behind the scene political advisor of the new rulers in addition to teaching at one of the run down universities in the City. Perhaps his only residual sense of pride is that he is the indisputable head of the Sheraton Six being the only $\mathrm{PhD}$ in the group and this explains his discomfort when a new member, another PhD from Dallas, is set to join them. Dr. Alex cuts the character of a hopeless and depressed individual. He was always drunk and his students enjoyed hearing him lecture in a 'slurred voice' which signifies the loss of his academic edge. Besides, unlike Tadesse who doubled as a well paid informer of the new government, Dr. Alex publicly defended the repressive government and people hated him for it. All these aggravated his frustrations. In fact, he was so depressed that the narrator compares him to 'the street boys who sniffed at rags soaked in petrol or glue to intoxicate themselves and not to feel the pain of hunger and daily misery' (Tuma, 2006, P.155). Furthermore, Ijigayehu who is informally referred to as Jiggy is not as highly educated as the others but is financially stable due the wealth she inherited from her late husband. She is however immoral and openly boasts of having 'tasted or bedded down most of the City's worthwhile bachelors and adulterous husbands' (P. 153). Her claim is corroborated when the narrator says that after a group's meeting she drove 'to a Villa in the old airport area where she woke up a certain clerk ... and took him back to her house for perfunctory but, for her, satisfactory sex' (pp. 163 - 164). Though Ijigayehu is adequately rich and good looking, she is dogged by inferiority complex that is only assuaged 'when she joined her intellectual friends in the Sheraton or heard the orgasmic screams of many a proud man lured to her bed' (p.155). Ijigayehu's affairs with lonely men or men for hire in clandestine sexual activities makes her immoral, exploitative and lacking in family values just like the rest of the group members. Indeed, Dr. Alex after twenty years in self imposed exile has no proper family while Abiyou is gay, and even the new member, a $\mathrm{PhD}$ in computer science 'divorced from a ravishing blond years ago' (P. 158). Muktar is also ridiculed for being unprincipled, opportunistic, traitorous, and corrupt despite his posturing as a radical patriot. He prides himself of having abandoned his university education at first year to join the underground movement in the fight against authoritarianism though his was a conformist pursuit since, the narrator affirms, not being a member of this group then was considered as swimming against the current. He was always a selfish individual: When the Red Terror begun, he betrayed his comrades and saved his life. He joined the government party, finished his studies, became a business man, engaged in illegal trade, became rich and when the new government came he expressed his support to the new rulers by publicly re-condemning his old organization and vowing loyalty to "the new democratic order" (p.154)

Tuma mocks the chicanery that pervades African intellectual clubs. Although the Sheraton Six project a united front and a close bond, this group is very fragile as its fibre is characterized by betrayal. They routinely gossip about each other and when the chips are down, they can hardly stand by one another. Although Muktar reassures everyone of the cohesiveness of the group, 'informal as we are, a tight group is what we are' (p. 158) upon the visit of their table by two political officers to announce the detention of Muktar, the other members disown Muktar describing him as a not very committed member of their group. It does not come as a surprise that of the Sheraton Six, it is only Muktar who does not have a short form for his name. Dr. Alex says, 'he does come to spend the evening with us. We just talk academia, you know' while Romy recollects: 'I think it is curious that he never took even one of us to his house. Simply curious, so much secrecy is not normal now that I come to think of it' (P. 165).

Although the colour Blue has been generally associated with tranquility, calmness, depth and expertise, in 'Sheratonians' the colour blue is used to suggest something improper. It is symbolically used to laugh at the notion that the local based intellectuals are more committed to the good of their mother country than the Ethiopians and by extension other Africans living abroad. Contrary to their belief, the home based intellectuals are depicted as leading a life of despondency characterized by alienation, loneliness, immorality, alcoholism, and with some being political stooges who fuel despotism. In raw hypocrisy however, they engage in spirited attacks against the foreign based elite in a conscious effort to conceal their inherent inadequacies.

\subsection{The Pickpocket and the Public}

Pick-pocketing is believed to be one of the oldest and most widespread crimes in the world mainly because of its relative safety. Jay Albanese is cited in Keohane (2011) arguing that pick-pocketing is a subtle theft that requires some amount of skill, finesse, cleverness, planning, and patience. 
Williams (2014) adds that the key requirement of a successful pickpocket is not having nifty fingers but a working knowledge of the loopholes in their victim's brains. Pickpockets thrive not only on distracting people but also by confidently directing their victim's mind towards something else. Tuma curves the leadership in the image of pickpockets in the character of Shasho Mamo - a leadership that exploits the poor masses and expects the exploited to remain submissive in their suffering. In 'The Incurable Hedonist', Mamo is accused of being a hedonist against a backdrop of the suffering masses. Schwarz et al (1994) define a hedonist as one who subscribes to the doctrine that pleasure is the highest good or lives a lifestyle devoted to pleasure. Mamo's lifestyle contrasts the life lived by the common citizenry. The condition of the masses is however not uncommon since 'in Ethiopia pain is for the people and pleasure for the Great Leader and his like' (Tuma, 1993, p.124). The accused is guilty of having engaged in sex beyond the stipulated limit for his class, being choosy about the food he eats, enjoying his meals, reading clandestine books, and distributing recipes to his accomplices. Mamo is therefore in the dock for living a luxurious life just like the leadership. This is criminal since he is craving for higher ideals which ordinarily should be mere abstractions for the common man. According to the prosecutor, hedonism is dangerous: 'It dissipates human energy, diverts attention to infinitely secondary, bourgeois and decadent pursuits. Its God is pleasure, its end is pleasure, its means is pleasure. It's all pleasure, pleasure, pleasure' (P.125). It is therefore satirical that the leadership is engaging in selfish pleasurable activities while the masses suffer a lot of pain. This is a total mockery of the leadership. When asked whether he believes hedonism is a crime, the accused responds: 'indulging in pleasure for the sake of pleasure so long as it makes one happy and does not make anybody else unhappy is, in my opinion, correct' (p. 127). This is an indictment of the government which is oppressive and unfeeling towards the masses who, despite their suffering, are expected to be happy. The accused argues that the morally acceptable hedonism should ensure that the happiness of the leadership does not infringe on the happiness of the citizens. From the foregoing, however, the masses are expected to be contented in their servitude and must not endeavour to be happy as this would be tantamount to 'stealing'. The prosecutor believes that 'the nation needs worthy citizens who feel the reality, who work as ordered, who do not dissipate their energy in trivial things' (p.128). In essence, the reckless ambitions of the poor people must be tamed so that they remain loyal and submissive.

It is said that pickpockets exhibit an incredibly alluring display of confidence and the ability to play mind games with their victims (Williams, 2014). They are quite suave in their mien just like Harry, in Coburn (2007), instructs Ray and Sandy who are apprentice pickpockets, to always avoid violence but ensure they travel in style and stay in only the finest hotels. The accused in 'Incurable Hedonist' leads a contradicting lifestyle. Despite his luxurious life, he is discovered to be a pickpocket to the consternation of the prosecutor who can hardly understand how a well dressed man, of course with ugly eyes, but still flashily dressed, can confess that he has never worked in any office but has been maintaining himself through pick-pocketing. The accused has been living a life that resembles that of the leadership. He conveys the picture of the leadership. Both the leadership and the pick pocket are exploitative and enjoy all their luxury at the expense of their victims. They both live off the sweat of others - the unsuspecting and ignorant masses. Since the leadership and the pick pocket trade in similar wares, the crime committed by the pick pocket is that he is a common citizen. The prosecutor categorically reminds him that he is a common citizen whose job is to work and not to aspire for happiness like a chosen leader since 'leisure belongs to the Great Leaders just as joy and pleasure ... the pain of the present must be borne by loyal citizens for the future to be a reality' (p. 129).

Like the authoritarian leadership that rides on the ignorance of the masses, the pickpocket has to be calculating and schematic for him to survive and above all to avoid being caught. Like George Appo - a pickpocket in Timothy Gilfoyle's A Pickpocket's Tale - the pickpocket is a 'good fellow' who unlike the other criminals avoids violence and exclusively employs wit and wile to eke out a living. The pickpocket epitomizes the face of the government that does not struggle with the people but still steals from them anyway and remains uncaught. The government subtly empties the pockets of the masses hence their persistent poverty, suffering, pain, starvation, and frustration. The judge, an agent of the government, in his ruling, downplays the crime of pick-pocketing and instead charges on the prosecutor accusing him of negligence of duty and even sentencing him alongside the pickpocket for wasting the time of the court and honoring petty criminals with grave accusations. The prosecutor is told: You should have checked the history of the accused before wasting our time here. A simple pickpocket has been brought here on charges of serious crimes ... it is a mockery of our court. The accused admits to being a pickpocket. In all my studies I have never heard of a pickpocket who can be a hedonist (p. 131) 
The judge interestingly down plays the accusation leveled against the pick pocket and instead lays all the blame on an irresponsible prosecutor. The narrator holds that ideally the pickpocket would have been given the death sentence but this does not come to pass. Passing the verdict of a death sentence in accordance with the law on the accused hedonist would suggest incrimination and a possible end to the lifestyle of the leadership and so the judgment remains hazy so as to protect the interests of the authoritarian rulers. The judgment magnifies the flaws of the prosecutor who has to be sacrificed to avoid a direct indictment of the overall leadership. The action of the judge against the prosecutor speaks of how junior staff can be readily sacrificed by the despots when it is all they need to sanctify their image.

\subsection{Conclusion}

This paper has critically analyzed various symbols of spite employed by Tuma in his selected short stories to deride authoritarian leadership. Through symbolism, Tuma indirectly but effectively chides the failures of the despots in society. A number of symbols have been discussed including the Kilil tether and the Queue for Bread which, though prized by the leadership, are used by the authorities to stifle the freedoms of the citizenry. The paper also explores the Alkash metaphor and how it typifies the despots and their hypocritical character. It further examines the symbolism behind the Blue Room, the Pick pocket, and how these symbols not only cast but also mock the despots and their hirelings in Tuma's short stories. These symbols generally unmask the hidden but negative character traits of the leadership thereby affirming the contention that Tuma deploys symbolism to express his contempt for the despots.

\section{References}

Ayittey, G. (2012). 'Defeating dictators' Speech given at the Oslo freedom forum, Retrieved from http://www.oslofreedomforum.com/speakers/georgeayittey.html)

Coburn, J. (Producer). (2007). Harry in your pocket. DVD

Gage, J. (1993). Color and culture: Practice and meaning from antiquity to abstraction. Berkely, C.A: University of California Press.

Gilfoyle, T. (2007). A pick pocket's tale: the underworld of the nineteenth century. New York. Chicago: W.W. Norton \& Company, Inc.

Haibing, Z. (2015). Symbolic meanings of colors in The Great Gatsby. Studies in literature and language. vol. 10 (6) $\mathrm{pp} 38-44$

Harcourt, B. (2011). Radical thought from Marx, Nietzsche, and Freud, through Foucault, to the present: Comments on Steven Luke's In Defence of False Consciousness Governance and Power. University of Chicago Legal Forum 29

Human Rights Watch. (2014). Country reports on human rights: Ethiopia. Washington: USDS

Human Rights Watch. (1997). Country reports on human rights: Ethiopia. Washington: USDS

Imbuga, F. (1987). Betrayal in the city. Nairobi: EAEP

Keohane, J. (2011, February 23). The last art of pick pocketing: why has the crime become so rare in the United States?

Leiter, B. (Ed). (2004). Hermeneutics of suspicion: Recovering Marx, Nietzsche, and Freud in The Future of philosophy. Oxford: Clarendon Press. (Pp $74-105)$

Matfess, H. (2015). Rwanda and Ethiopia: Development authoritarianism and the new politics of African strong men. African Studies Review, 58, pp $181-204$

Nietzsche, F. (2000). Genealogy of morals, in The basic writings of Nietzsche, trans. Walter Kaufmann. New York: Random House

Ricoeur, P (1998). Hermeneutics and the human sciences. (Ed. \& Trans by Thomson, J.) Cambridge: CUP

Schwarz, C. et al (1994). The Chambers dictionary. Edinburg: Chambers Harrap Publishers Ltd.

Sloane, P. (1991). Primary sources, selected writings on color from Aristotle to Albers. New York: Design Press.

Tuma, H. (2006). The case of the criminal walk and other stories. Parker, Colorado: Outskirts Press.

(1993). The case of the socialist witchdoctor and other stories. London: Heinemann.

Wells, S. (1989). An Oxford Anthology of Shakespeare. Oxford: OUP

Williams, C. (2014, November 18). How pickpockets trick your mind. BBC, London. 